FILOZOFIA

Roč. 74, 2019, č. 9

DOI: https://doi.org/10.31577/filozofia.2019.74.9.3

\title{
MILLOVA MYLNÁ VÝHRADA PETITIO PRINCIPII VOČI DEDUKTÍVNEJ LOGIKE
}

FRANTIŠEK GAHÉR, Katedra logiky a metodológie vied, Univerzita Komenského v Bratislave, Bratislava, SR

GAHÉR, F.: Mill's Mistaken Objection of Petitio Principii Against Deductive Logic FILOZOFIA, 74, 2019, No 9, pp. 721 - 734

The critique of logic, as it was taught on the British Isles, intensified at the beginning of the 19th century. A systematic critique of Aristotelian (syllogistic) logic was undertaken from the standpoint of common sense philosophy chiefly by Scottish philosophers, followers of T. Reid. E. Copleston of Oxford came to logic's defense. His student, R. Whately, later wrote the textbook Elements of Logic (1826), in which he replied to the objections of Scottish philosophers. The textbook correctly explains that systems of deductive logic need not suffer from the petitio principii fallacy. J. S. Mill at first wrote a positive review of the textbook, but later published his System of Logic. In it, he puts forward the contrary view when evaluating the role of Aristotelian (deductive logic), objecting to the supposedly irredeemable fallacy of petitio principii. The fallacy can be avoided, he argues, in an inductive logic proposed by him. Mill's objection to the Aristotelian syllogism was based on a misunderstanding of the analytic novelty of the knowledge contained in the conclusion of a valid argument. Mill's explication of logic is contradictory, based on an associative psychologism and sensualism. The objection against deductive logic is simply mistaken. Mill's logic and his positions were very critically appraised already by S. Jevons and the standard overviews of the history of logic fail to mention it.

Keywords: Petitio principii - Syllogism - Deductive logic - Inductive logic Mill, J. S.

\section{Historická predohra (prvé štádium): pálenie kníh z logiky}

Môže sa zdat', že na to, aby študenti získali k niektorému predmetu výučby nechut', či dokonca odpor, netreba splnit' vel'a podmienok. Dôležitým faktorom pri vytváraní vzt'ahu študenta $\mathrm{k}$ predmetu je učitel' a jeho spôsob výučby tohto predmetu. Ked' študenti skladajú o odbore a učitel'ovi sarkastické pesničky a vtipy, je to príznak kritického, azda až negatívneho vzt’ahu k nemu. Ked' však pália učebnice $\mathrm{z}$ tohto odboru, je to jednoznačný signál nenávisti $\mathrm{k}$ celému odboru. Toto sa 
prihodilo logike na Trinity College v Dubline v polovici 18. storočia (Jongsma 1982, 240). A treba zdôraznit', že nešlo o ojedinelý prípad, ale o pravidelne každoročne opakovaný demonštratívny akt, ktorý uskutočňovali generácie študentov. Išlo o učebnicu z pera Franca Burgersdiciusa (Burgersdijk) Institutionem Logicarum,${ }^{1}$ používanú od roku 1730 ako základný text z logiky. Študenti ju pokladali za takú nudnú a odpudzujúcu, že kandidáti na bakalára ju vždy po zložení skúšky pálili s nádejou, že bude vyradená z používania. Neboli úspešní a text sa používal aj po roku 1745. Nenávist' $\mathrm{k}$ logike len málo zmiernila učebnica, ktorá ju neskôr nahradila (tiež v latinčine) od Richarda Murrayho Artis Logicae Compendium z roku 1759, ktorá bola podl'a Jongsmu kompromisom medzi aristotelovskou logikou a žiadnou logikou a v ktorej zdôvodnenie potreby logiky bolo nepresvedčivé (Jongsma 1982, 241).

2. Historická predohra (druhé štádium): z dažd’a pod odkvap - logika Henryho Ketta Na Trinity College v Oxforde Henry Kett od roku 1802 používal príručku Elements of General Knowledge ... ${ }^{2}$ (Kett, 1802). V druhom diele tohto dvojzväzkového diela Logic, or the Right Use of Reason bola predstavená logika bez technických detailov, skôr však ako karikatúra, než ako solídna expozícia logiky (Kett, 1802, 64). Kett vyzdvihoval oproti aristotelovskej logike (sylogizmu) induktívnu logiku vel'kého lorda Francisa Bacona ako efektívnejší nástroj na ceste k pravde (Kett, 1802, 68). V roku 1809 publikoval učebnicu o aristotelovskom sylogizme Logic Made Easy... (Kett, 1809), kde sa podla Jongsmu nádejal, že zjednodušil a sprístupnil aristotelovskú logiku študentom a uskutočnil syntézu aristotelovskej a Baconovej logiky (Jongsma 1982, 271). Táto učebnica je však hodnotená ako konfúzny a značne nekonzistentný konglomerát ideí:

„Nanešt’astie, Kett neuchopil logiku adekvátne a jeho zjednodušenia v skutočnosti prinášajú nejasnosti, a niekedy úplné nezmysly do logiky“ (Jongsma 1982, 274).

Whately $(1854,92,94)$ si neskôr spomínal, že vyučovanie takto zdeformovanej logiky viedlo k jej hlbokému odsúdeniu: aristotelovská logika je vraj rovnako neužitočná a zastaraná ako chiromantia či alchýmia a astrológia a jej postavenie sa prirovnávalo $\mathrm{k}$ prekonanej Aristotelovej fyzike.

\footnotetext{
${ }^{1}$ Institutionum logicarum libri duo vydali Bonaventura Elzevier a Abraham Elzevier. Prvýkrát bola vydaná v Leydene v roku 1626 a o rok neskôr sa stala oficiálnou učebnicou. V roku 1637 ju vydali aj v Cambridgei a spolu mala dvadsat'sedem vydaní.

2 Jej úspech dokumentuje pät' vydaní v 1803; deviate vydanie je z roku 1825 (Jongsma 1982, 268).
} 
3. Kritika Ketta zo strany Edwarda Coplestona ako zástancu aristotelovskej logiky Edward Copleston učil v Oxforde na Oriel College od roku 1797 logiku v intenciách rozšíreného kompendia Henryho Aldricha, ktorá sa zvykla nazývat' jednoducho $O x$ fordská logika (Aldrich, 1750). Copleston bol konfrontovaný s rastúcim všeobecným odporom voči logike a z čiastočnej oprávnenosti kritiky logiky a jej výučby obviňoval práve pôsobenie Ketta. Preto Copleston vystúpil s kritikou Kettových prác a v roku 1809 publikoval anonymný pamflet s priliehavým názvom Vyskúšaný skúšatel' alebo logika zbavená viny... (Copleston, 1809). Hoci bol pamflet plný sarkazmu a obviňovania, predsa bol podporený spol’ahlivými argumentmi. Podla Coplestona sa Bacon st’ažoval, že logika nie je vhodný nástroj na objavovanie právd prírody. Copleston vyjasnil vzt'ah induktívnej logiky a sylogistiky: ${ }^{3}$ sylogistika ako proces, ktorý je odlišný od objavovania (empirických) právd prírody, nemá byt' obviňovaná z toho, že nedosahuje ciele, aké si nikdy nepredsavzala. Odmietol návrh, aby induktívna logika nahradila vo výučbe (aristotelovský) sylogizmus. Rozlíšil dva pojmy indukcie, a to indukciu ako argumentáciu a indukciu ako objavovanie nových právd.

Copleston akceptuje Aldrichovo vysvetlenie indukcie ako argumentácie: premisa minor tvrdí, že určitý počet indivíduí má tú a tú vlastnost' a premisa major (hlavná premisa) tvrdí, že ak akúkol'vek vlastnost' majú tieto indivíduá, tak ju majú aj všetky indivíduá, ktoré patria do tejto triedy. Dnes by sme v predikátovej logike druhého rádu mohli túto schému indukcie (SchInduk) zachytit' takto:

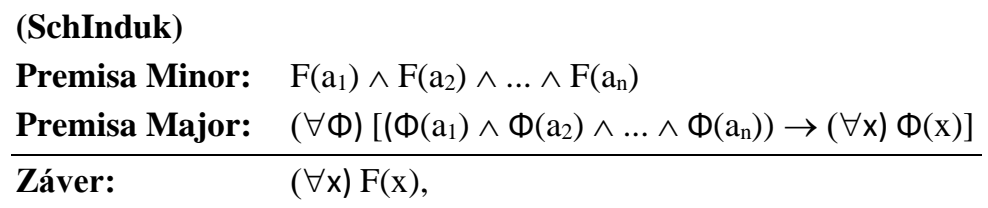

kde F vyjadruje určitú vlastnost', $\mathrm{a}_{1}$ až $\mathrm{a}_{\mathrm{n}}$ označujú indivíduá, $\Phi$ je predikátová premenná, ktorá zastupuje vlastnosti, $\wedge$ je konjunktor, $\rightarrow$ je implikátor a $\forall$ je všeobecný kvantifikátor.

Toto je vlastne schéma deduktívne platného argumentu a jeho spol'ahlivost' závisí od toho, či (1) tieto skúmané indivíduá skutočne (pravdivo) reprezentujú všetky indivíduá z triedy, teda či (2) je induktívna premisa pravdivá.

Schéma úsudku s vypustenou hlavnou premisou má známu formu indukcie: ak nejakú vlastnost' majú indivíduá $\mathrm{a}_{1}$ až $\mathrm{a}_{\mathrm{n}}$, tak ju majú všetky indivíduá. Preto sa aj takéto argumenty nazývajú induktívne argumenty:

\footnotetext{
${ }^{3}$ Sylogistikou sa myslel aj kategorický sylogizmus (aristotelovská logika) aj hypotetický sylogizmus (výroková logika). Tretím typom sylogizmu bol práve induktívny sylogizmus.
} 


\section{(Induk)}

$$
\begin{aligned}
& F\left(a_{1}\right) \\
& F\left(a_{2}\right) \\
& \cdot \\
& \cdot \\
& \frac{F\left(a_{n}\right)}{(\forall x) F(x)}
\end{aligned}
$$

resp. induktívnej implikácie:

$$
\left(\mathrm{F}\left(\mathrm{a}_{1}\right) \wedge \mathrm{F}\left(\mathrm{a}_{2}\right) \wedge \ldots \wedge \mathrm{F}\left(\mathrm{a}_{\mathrm{n}}\right)\right) \rightarrow(\forall \mathrm{x}) \mathrm{F}(\mathrm{x}) .
$$

Tieto schémy nie sú schémy deduktívne platných argumentov - vzt'ah medzi premisami a záverom môže mat' povahu napríklad pravdepodobnostnej relácie 4 .

Zoslabená forma induktívneho úsudku so singulárnym záverom (SingInduk) má nasledovný tvar:

$\begin{array}{ll}\text { (SingInduk) } & F\left(a_{1}\right) \\ & F\left(a_{2}\right) \\ \cdot \\ \cdot \\ \cdot \\ \underline{F\left(a_{n}\right)} \\ F\left(a_{n+1}\right)\end{array}$

Copleston pokladal logiku za sémantický základ pre správne usudzovanie - poznanie logiky nám umožňuje použit jazyk na komunikáciu názorov a úsudkov, na konštruovanie správnych argumentov. Logika podl'a neho umožňuje rozlišovat' správne a nesprávne argumenty a odmietat' sofizmy.

\section{Walker a Kirwan ako obhajcovia sylogistiky}

Copleston nebol vo svojich názoroch celkom osihotený - John Walker v roku 1805 prvýkrát publikoval latinsko-anglickú verziu Murrayho učebnice (Walker, 1805). Tento text bol lepší ako text pôvodného autora a používal sa až do roku $1885 .{ }^{5}$ Walker na rozdiel od nepresvedčivého Murrayho jednoznačne obhajoval užitočnost' logiky najmä pre jasné a presné usudzovanie. Na druhej strane pripúšt’al, že argumentácia

\footnotetext{
${ }^{4}$ Bližšie o induktívnych úsudkoch pozri napr. Bielik (2019, 106 a n.).

${ }^{5}$ Vo vydaní z roku 1847 boli zohl'adnené aj názory Whatelyho, Milla a iných autorov učebníc logiky.
} 
nemusí byt' len sylogistická (aristotelovská), čo je podl'a neho privel'mi skostnatené. Práve logika nám pomáha odliśsit' platné argumenty od neplatných. Z týchto dôvodov odmieta Lockeovu kritiku sylogistiky. Podla Walkera Locke nemal hlboké a presné poznanie aristotelovskej logiky. Podl'a neho má však Locke pravdu v tom, že logika nie je nástrojom vedeckého (empirického) objavovania, ale nemá pravdu v tom, ked' hovorí o chybách v Aristotelovej logike (Walker's Murray 1805, 94).

Na obranu sylogizmu pred Lockom sa podujal aj Ír Richard Kirwan, ktorý v roku 1807 publikoval prácu Logick; or, An essay on the elements, principles, and different modes of reasoning. Kirwan pripúšt’a, že záver úsudku je implicitne obsiahnutý v premisách (Kirwan, 1807, 482). V analýze dôkazu sporom, ktorú predložil George Campbell (Jongsma 1982, 254), jeden z predstavitel’ov škótskej filozofie zdravého rozumu spolu s Lockom vytýka sylogizmu chybu petitio principii.

Chyba petitio principii (,požadovanie začiatku“; begging the question) je charakterizovaná ako kruhovost' argumentácie a môže mat' rôzne podoby. To, čo má byt' argumentáciou dokázané, sa už predpokladá ako platné, pričom to môže byt' zjavné a argumentácia je bezprostredne kruhová, alebo je to kruhovost' sprostredkovaná či zamlčaná.

Kirwan voči Campbelovi namieta, že predložená analýza má formu sylogistického úsudku, ale netrpí žiadnou chybou petitio principii. Kirwan to výstižne uzatvára: „Ak by tam bola (chyba petitio principii), tak je nezvyčajné, že ostrozrakí scholastici nikdy neobjavili tento zásadný defekt“ (Kirwan 1807, 527). Treba však poznamenat', že osnova nepriameho dôkazu je založená na výrokovej logike (vtedajšom hypotetickom sylogizme), nie na aristotelovskom sylogizme, na ktorého kritiku - ako uvidíme neskôr - sa Mill výlučne sústredil. Jongsma je presvedčený, že Kirwan bol prvý, kto sa vyjadril ku kritike kruhovosti z pozície tradičnej logiky (Jongsma 1982, 255).

\section{Mnohohlavý drak (škótskej) Edinburg Review, ktorý útočí na Oxford na mno- hých frontoch}

\subsection{Drak č. 1: John Playfair}

V roku 1808 John Playfair publikoval anonymnú recenziu Laplaceovho Traité de méchanique céleste $\mathrm{v}$ Edinburgh Review. ${ }^{6} \mathrm{~V}$ poznámkach $\mathrm{k}$ britskej matematike konštatoval jej zaostávanie za kontinentálnou - analytickou matematikou (Playfair 1808, 281 a n.). Dôvody videl v preferovaní syntetického, geometrického prístupu k matematike, podl'a neho vo výučbe matematiky prevládajú katechetické

${ }^{6}$ Traité de méchanique céleste, Edinburgh Review, January 1808, 11 (22), 249 - 284. 
metódy (biflovanie) a medzi príčinami úpadku videl aj aristotelovskú logiku a jej zdanlivo neomylné konštatácie (Playfair 1808, 283 - 284), čo bola jediná výhrada voči logike. Zodpovednost' za tento neutešený stav prisúdil Royal Society, ale podiel viny na tomto neutešenom stave mali podl'a neho verejné inštitúcie, najmä však dve centrá rozširovania poznania (myslel tým univerzity v Oxforde a Cambridgei).

\subsection{Prvá obranná reakcia Coplestona a protiútok trojhlavého draka č. 2}

Playfairovo znevažovanie dobrého mena Oxfordu priviedlo Coplestona k obrane: v roku 1810 publikoval anonymný stodevät'desiatstranový pamflet (Copleston, 1810), ktorý mal vel'ký ohlas.

V apríli 1810 nasledoval „odpal“ v Edinburgh Review z pera Playfaira a jeho dvoch kolegov Payne Knighta a Sydney Smitha. ${ }^{7}$ Aristotelova logika je podl'a nich osobitne nepriatel'ská voči induktívnej vede: „Zameraním mysle na sylogistické metódy sa stáva vel'mi silnou prekážkou pre poznanie, ktoré je odvodené indukciou na základe skúsenosti a pozorovania“ (Playfair, Knight, Smith 1810,161). Ohlasujú nástup Bacona a jeho novej éry, pričom vyčítajú, že vo výučbe v Oxforde nie je ani zmienky o Baconovom Novom Organone. Prívržencov aristotelovského sylogizmu prirovnávajú k inžinierovi, ktorý namiesto konštrukcie parného stroja podl’a návodu Watta či Boltona preferuje nejaký staroveký plán (Playfair, Knight, Smith 1810, 162).

\subsection{Druhá Coplestonova obrana a dva protiútoky - jeden $\mathrm{z}$ pera draka č. 4 Drummonda}

Ešte v tom istom roku publikoval Copleston druhú repliku - stodvadsat'stranový pamflet A Second Reply... (Copleston, 1810). V auguste 1810 John Davidson publikoval anonymnú recenziu v Quaterly Review, v ktorej ho podporoval. Podl'a neho napätie medzi logikou a vedou šíri Thomas Reid, ktorý však pochopil Bacona skreslene (Jongsma 1982, 299). Vzápätí draci z Edinburg Review zmizli zo scény, okrem Playfaira. Ten v novembri 1810 v recenzii Woodhausovej Trigonometry ${ }^{8}$ spochybnil oxfordské, ale aj Coplestonovo matematické poznanie, no o Aristotelovi a jeho sylogistike sa vôbec nezmienil. Na konci roku Henry Drummond, Škót, ktorý predtým navštevoval Univerzitu v Oxforde, publikoval devät'desiatstranový kritický pamflet o vzdelávaní v Oxforde (Drummond, 1810).

\footnotetext{
${ }^{7}$ Knight, R. P., Playfair, J., Smith, S. (april 1810): Calumnies Against Oxford. (Review of E. Coplestone 1810 Reply): Edinburgh Review, 16 (31), 158 - 187.

${ }^{8}$ Woodhaus's Trigonometry. Edinburgh Review, 17 (33), 122 - 135.
} 


\subsection{Tretia Coplestonova obrana}

V nasledujúcom roku Coplestone publikoval tretiu, ale už ovel’a kratšiu (štyridsat' strán) repliku (Coplestone 1811), v ktorej reagoval na „posledného“ Playfaira a Drummonda.

Dúfal, že „,nespokojenci s Aristotelom hádam prekonajú v ignorancii a hlúposti jeho (Aristotelových) najoddanejších prívržencov“ (Jongsma 1982, 289). Vyzdvihol jadro Aristotelovej filozofie a logiky ako ríšu zdravého úsudku a rozumu a odmietol jej zneužitie na umenie diskusného zápasenia. Bacon, Locke, Reid, Kame a iní podobne zmýšlajúci podl'a neho sústavne skreslene vysvetl'ovali čitatel'om aristotelovskú logiku a doviedli mnohých k zablúdeniu nesprávnou kritikou Aristotela a jeho sylogizmu (Jongsma 1982, 290). Upozorňuje na nesprávny Playfairov úsudok, podla ktorého pretože sa učí aristotelovská logika, neučí sa (prírodná) veda. Podl’a Coplestona je to podobne chybný úsudok ako: pretože sa učí gréčtina, latinčina je zanedbávaná (Jongsma 1982, 296).

V apríli 1811 v British Critic jeden sympatizant Coplestona sumarizoval stav a zdalo sa, že problém je už definitívne odstránený.

\section{Whately zabránil akademickému vyhynutiu logiky v Oxforde}

Whately na podnet svojho učitel'a Coplestona publikoval najprv vo forme článku v Metropolitnej encyklopédii v roku 1823, a neskôr v roku 1826 už napísal na svoj čas modernú učebnicu Elementy logiky, ktorou spolu s učitel'ským pôsobením podla niektorých autorov zabránil akademickému vyhynutiu logiky v Oxforde (Jongsma 1982, 433). Whately v zásade správne vysvetlil úlohu sylogizmu ako nástroja rozširovania poznania a chybu petitio principii charakterizoval tak komplexne a výstižne, že celú pasáž zvyknú citovat' moderní autori, ktorí píšu o chybách usudzovania (napr. Hamblin 1970, 34).

V prípade chyby petitio principii hovorí vlastne o dvoch typoch chyby kruhovosti, ktoré by sme dnes označili ako logicko-sémantický a epistemický typ chyby:

1) O logicko-sémantickú chybu (v našej terminológii) ide podl’a Whatelyho vtedy, ked’ premisa má zjavne ten istý význam ako záver, alebo je v skutočnosti z neho odvodená;

2) O epistemickú kruhovost' úsudku ide vtedy, ked' evidencia premisy je založená na evidencii záveru:

„Premisa je taká, že osoba, ktorej je adresovaná, nie je ochotná ju poznat' či pripustit', pokial' nie je odvodená zo záveru“ (Whately 1826, 220).

Ako príklad uvádza vlastne istú schému vysvetlenia: 
„Niekto usudzuje na skutočný priebeh určitej histórie na základe záznamu takých a takých faktov, ktorých reálnost' spočíva na evidencii tejto histórie“" (Whately 1826, 220).

V prípade úsudku, ktorý trpí epistemickou kruhovost’ou, nemusí íst' o logickú chybu - záver môže byt’ platný, ale premisa nie je oprávnená - nie je evidentnejšia ako záver, nemôžeme ju poznat', kým nepoznáme záver.

Odmietol výhradu, že deduktívne úsudky trpia chybou petitio principii (Whately 1826, 220 - 221) a predložil v zásade správne stanovisko, podl'a ktorého novost' záveru deduktívneho úsudku netkvie v novosti jeho fyzikálneho (myslel empirického) poznania voči premisám, ale v novosti logického poznania (Whately 1826, 276). Whately vysvetl'uje, že dedukcia sa týka odhal'ovania potenciálnych právd, obsiahnutých implicitne či virtuálne $\mathrm{v}$ premisách, naproti tomu indukcia ako usudzovanie z jednotlivých prípadov na čiastočný záver sa týka objavovania bezchybných a náležite nových právd (Whately 1826, 276 - 277).

Z Whatelyho logiky sa učili okrem Milla (preňho to bola jediná z prečítaných prác z logiky, ktorá nebola staršia ako sto rokov) mnohí - napríklad aj August De Morgan aj George Boole.

\section{Millova kladná recenzia Whatelyho Elementov}

Mill v rozsiahlej recenzii hodnotil Whatelyho učebnicu jednoznačne pozitívne:

„,... práca obsahuje jasnú expozíciu princípov sylogistickej logiky a obraňuje ju voči súdobému sarkazmu niektorých moderných metafyzikov“(Mill $\left.1828,137 / 3^{9}\right)$.

V hodnotení súperenia zástancov a odporcov logiky konštatuje - aj ked' zatial' len dočasné - vít’azstvo zástancov logiky:

„Autority škótskej filozofie (dr. Reid a nasledovníci), ktorých spisy za posledných 50 rokov sa stali baštou nepriatel'stva voči Logike, boli na určitý čas rozložené“ (Mill 1828, 137/3).

Jongsma toto Millovo hodnotenie literárne nadnesie:

„... škótska filozofia zdravého rozumu bola dobrá $\mathrm{k}$ smrti a Whately urobil všetko nevyhnutné pre oživenie aristotelovskej logiky“ (Jongsma 1982, 415).

\footnotetext{
${ }^{9} \mathrm{Za}$ lomkou je uvedené stránkovanie reedície z roku 1978.
} 
$\mathrm{V}$ recenzii však nie je ani zmienka o chybe petitio principii. Whatelymu vcelku neútočne vytýka, že na zdôvodnenie potreby logiky použil apriórny argument. Podl'a Milla však ten, kto ignoruje logiku, nemôže pochopit' jej užitočnost'. A ten, kto vie správne usudzovat', ten nepotrebuje zdôvodnenie (Mill 1828, 142/5). Mill v recenzii hovorí o tých, ktorí navrhujú induktívnu logiku namiesto sylogizmu a opisuje Whatelyho obranu aristotelovskej logiky (Mill 1828, 143/6). Výstižná je Millova poznámka o zdravom rozume, ktorý považuje za nášho výborného sprievodcu, ale v poradí až druhého, ved' aj námorník, ktorý sa bežne riadi zdravým rozumom, pri navigácii na mori rešpektuje princípy navigačného umenia.

Mill súhlasí s Whatelym v odmietaní doktríny moderných metafyzikov, spletenej s absurditami učencov, ked' usudzujú podl'a sylogizmov z nepravdivých premís na absurdné závery (Mill, 1828, 149/12). Moderní filozofi, ktorí toto pochopili, podla Milla podporujú využitie indukcie namiesto sylogizmu. Chybou učencov však podl'a neho nebolo to, že by popierali indukciu. Jasne vedeli, že filozofovanie je založené na dvoch krokoch: na zistení premís a na dedukcii záverov. Vedeli, že pravidlá sylogizmu sa týkajú len druhého kroku (usudzovania), ktoré bráni odvodeniu takých záverov, ktoré nie sú garantované premisami. Samo usudzovanie ale neponúka žiadny test pravdivosti pôvodných premís, ktoré nie sú dedukované z nejakých prvotnejších právd. Podla Milla evidencia týchto premís je odvodená zo skúsenosti a proces ich získavania sa nazýva indukcia, o čom podl'a neho hovoril už Aristoteles.

Induktívna logika je podla Milla vhodná na objavovanie právd matematiky, astronómie a mechanickej filozofie (fyziky), pre vel'kú čast' právd morálky, politiky a filozofie mysle. Obmedzené využitie má však podl'a Milla v chémii a fyziológii. Nie je však vôbec jasné, ako by indukcia mala pomáhat' objavovaniu právd v týchto disciplínach, pretože neuvádza žiadne príklady využitia induktívnej logiky v týchto oblastiach.

Mill v recenzii ešte nepreferuje induktívnu logiku pred sylogizmom a reprodukuje Whatelyho názor na ňu ako len vel’mi užitočný doplnok k nemu, avšak taký, ktorý ho nenahrádza. Cituje Whatelyho dokreslenie tohto vysvetlenia prirovnaním ku vzt’ahu pluhu a cepu:

„Pluh môže byt’ pôvodnejší a cennejší nástroj ako cep, ale nikdy ho nenahradí..." (Whately 1826, 236; Mill 1828, 152/14).

\section{Millov obrat proti deduktívnej logike}

V roku 1843 Mill publikuje svoj Systém logiky, kde aristotelovskému sylogizmu vytýka zásadnú chybu petitio principii. Chybu petitio principii charakterizuje ako to, že v závere takýchto úsudkov nie je o nič viac (poznania) ako v premisách (Mill 1843, 183). Môžeme hovorit' o Millovom obrate proti deduktívnej logike, 
ked’že niektorí autori (Hamblin 1970, 35, Biro 1977, 257) prisudzujú Millovi názor, ktorý vlastne zastával už Sextus Empirikus, že každý deduktívne platný argument trpí chybou petitio principii. To je podl'a Milla pravda, ale musíme konštatovat', že zároveň podl'a Milla „názor, že petitio principii je obsiahnutý v každom sylogizme, je zásadne chybný“ (Mill 1843, 183). Jednoducho tu treba rozlišovat' najmenej tri druhy sylogizmov: 1) aristotelovský sylogizmus, ktorý chybou nerozširovania poznania obsiahnutého v závere podl'a Milla trpí; 2) hypotetický sylogizmus, ktorý Mill z hl'adiska možnej chyby kruhovosti argumentov vôbec neskúma; ${ }^{10} 3$ ) induktívny sylogizmus, ktorý jediný touto chybou podl'a Milla netrpí, a preto má byt' pre vedu jednoznačne prínosnejší práve induk tívny sylogizmus.

Inšpiráciou v tomto Millovom obrate proti celej deduktívnej sylogistike bola staršia práca Reidovho „spolubojovníka“ a nasledovníka Dugalda Stewarta Elements of the Philosophy of the Human Mind z roku 1814, ktorú recenzoval ešte Johnov otec - James Stuart Mill. Podl'a jeho vlastného svedectva (Mill 1873, 189 - 190) pochybnosti o správnosti Whatelyho vysvetlenia sa uňho objavili už v roku 1830 po opakovanom čítaní práce Stewarta.

Paradigmatickým typom úsudku, ktorý vraj trpí chybou petitio principii, je pre Milla známy úsudok o Sokratovej smrtel'nosti ${ }^{11}$ (Mill 1843, 184):

(U1) Všetci l'udia sú smrtel'ní

Sokrates je človek

Sokrates je smrtel'ný

Podl'a Milla neusudzujeme zo zapamätaného všeobecného výroku, ale z predchádzajúcej skúsenosti: „Jediné, čo môžeme odvodit’ z pamäti, je naše vlastné predchádzajúce presvedčenie, týkajúce sa odvodení, ktoré by predchádzajúca skúsenost' oprávňovala“" (Mill 1843, 184).

Vzápätí Mill predkladá vcelku vel'mi kuriózne zdôvodnenie rovnakého typu úsudku, v ktorom však hlavnou postavou je vtedy ešte živý Vojvoda z Wellingtonu:

„Pravdivý dôvod, prečo sme presvedčení, že Vojvoda z Wellingtonu umrie, je, že jeho otec a náš otec a všetky s nimi súdobé osoby zomreli. ... Nie je žiadny rozpor v predpokladaní toho, že všetky tieto osoby zomreli a že Vojvoda z Wellingtonu môže napriek tomu žit' navždy“ (Mill 1843, 185).

\footnotetext{
${ }^{10}$ O neudržatel'nosti Millovho chápania hypotetického sylogizmu bližšie pozri Gahér (2019, 266 a n.).

${ }^{11}$ Hansen (2019) tento príklad úsudku už nezarad'uje medzi tie, ktoré by mohli trpiet' chybou petitio principii, pretože jeho všeobecná premisa je odvoditel'ná zo všeobecnejších právd o živočíchoch.
} 


\section{Mill rezignuje na všeobecné poznanie analytického typu}

Mill si uvedomil, že k jeho programu indukcionistického zdôvodnenia poznania je vážnou prekážkou analytické poznanie matematiky a geometrie. Preto sa snažil spochybnit' všeobecné poznanie analytického typu a kritizuje Whatelyho za to, že nevie vysvetlit', ako môže byt' veda ako geometria odvodená z niekol'kých definícií a axióm. Sám uvádza príklad úsudku z geometrie o rovnosti úsečiek bez všeobecnej premisy o tranzitívnosti a symetrickosti rovnosti:

$$
\begin{aligned}
& \mathrm{AB}=\mathrm{EF} \\
& \mathrm{CD}=\mathrm{EF} \\
& \mathrm{AB}=\mathrm{CD}
\end{aligned}
$$

Zároveň sa v komentári vyjadruje naozaj nelogicky, ked’ z explicitne neplatného úsudku bez všeobecnej premisy o tranzitívnosti a symetrickosti rovnosti robí priam zázrakom platný argument:

„V určitých prípadoch môže byt' všeobecný výrok vypustený bez toho, aby (argument) stratil svoju dôkaznú silu“ (Mill 1843, 145).

Pripomeňme, že Millov projekt empirického vysvetlenia povahy aritmetiky a samého pojmu čísla stroskotal, ako neskôr podrobne demonštroval už Gotlob Frege v Základoch aritmetiky (Frege, 2002).

\section{Mylnost' Millovej výhrady voči deduktívnej logike}

Novost' poznania Mill spájal iba s empirickým poznaním a zrejme nepochopil novost' $\mathrm{v}$ oblasti analytického poznania, ktoré chcel tiež zdôvodnit' induktívne. Jedným z faktorov tohto nepochopenia okrem odmietania konceptuálneho poznania vo forme všeobecných analytických propozícií bola neschopnost' odlíšit' implicitnú obsiahnutost' záveru v premisách od explicitnej neobsiahnutosti. O Sokratovej smrtel'nosti sa v premisách úsudku (U1) nič netvrdí, tento záver nie je explicitne obsiahnutý vo všeobecnej premise a je tak novým poznaním, ktoré logická fantázia deduktívne vydolovala $\mathrm{z}$ premís a explicitne uviedla $\mathrm{v}$ závere. Rovnako ako tento úsudok, ani iné deduktívne platné úsudky so závermi odlišnými od premís netrpia chybou petitio principii, ako ju sformuloval Mill. Relácia odlišnosti záveru od premís však musí byt' dostatočne jemná - na úrovni granularity hyperintenzionálnej logiky, ktorá rozlišuje aj medzi intenzionálne ekvivalentnými významami propozícií. Zápas o aktuálne chápanie chyby petitio principii aj z logického aj z epistemologického pohl'adu, ako o nej hovorí napríklad Hansen (2019), prekračuje zámer tejto state a mienime mu venovat' osobitný článok. 
Millovo zdôvodnenie induktívneho sylogizmu sa opiera o podobnost', analógiu prípadov, ktorých evidencia je založená na priamom pozorovaní alebo svedectve, pričom ich epistemické zdôvodnenie je založené na asociatívnom psychologizme. Známe je vel'mi kritické hodnotenie Milla ako v týchto otázkach nelogického autora z pera Williama Stanley Jevonsa (Jevons 1877a, 169; 1878, 256). Kriticky Milla hodnotí v tomto ohl'ade aj Charles Leonard Hamblin $(1970,247)$.

\section{Záver}

O tomto zápase o logiku, ktorý sa udial v prvej polovici devätnásteho storočia na britských ostrovoch, o jeho podobách a o zdanlivom prínose Millovej logiky k svetovej logike nenájdeme v uznávaných prehl'adoch dejín logiky z pera Józefa Bocheńskeho (Bocheńsky,1961) či Williama a Marthy Knealle (Knealle \& Knealle,1962) ani len zmienku. Prelom v rozvoji logiky sa podl’a týchto prehl'adov spája až s dielami $\mathrm{Au}-$ gusta De Morgana a Georga Boolea. Vzhl'adom na neudržatel'nost' Millových názorov na deduktívnu logiku je toto hodnotenie oprávnené.

\section{Literatúra}

ALDRICH, H. (1750): Artis Logicae Compendium. Oxford: E Theatro Sheldoniano.

BACON, F. (1974): Nové organon. Praha: Svoboda.

BIELIK, L. (2019): Metodologické aspekty vedy. Bratislava: Vydavatel'stvo Univerzity Komenského. BIRO, J. I. (1977): Rescuing 'begging the question'. Metaphilosophy, 8, 257 - 271.

BOCHEŃSKY, J. M. (1961): a History of Formal Logic. Notre Dame: University of Notre Dame Press.

BOTTING, D. (2014): Do Syllogisms Commit the Petitio Principii? The Role of Inference-Rules in Mill's Logic of Truth. History and Philosophy of Logic, 35 (3), 237 - 247.

COPLESTON, E. (1809): The Examiner Examined, or Logic Vindicated. Addressed to the Junior Students of the Univesity of Oxford. By a Graduate. Collingwood and Co. Oxford.

COPLESTON, E. (1810): A Reply to the Columnies of the Edinburgh Review against Oxford. Containing an Account of Studies persued in that University. Oxford.

COPLESTON, E. (1810): A Second Reply to the Edinburgh Review. By the Author of Reply to the Columnies of that Review against Oxford. Oxford.

COPLESTON, E. (1811): A Third Reply to the Edinburg Review. By the Author of Reply to the Columnies of that Review against Oxford. Oxford.

De MORGAN, A. (1847): Formal Logic: Or, The Calculus of Inference, Necessary and Probable. London: Taylor and Walton.

DRUMMOND, H. (1810): Observations, suggested by the Strictures of the Edinburg Review upon Oxford; and by the two replies, containing some account of the late changes in that University. Edinburgh.

DUCHEYNE, S., McCASKEY, J. (2014): The Sources of Mill's View of Ratiocination and Induction. In: LOIZIDES, A. (ed.) (2014): Mill's System of Logic: Critical Appraisals, London: Routledge. 
DUŽÍ, M. (2010): The Paradox of Inference and the Non-triviality of Analytic Information. Journal of Philosophical Logic, 39 (5), 473 - 510.

FREGE, G. (2002): Základy aritmetiky. Bratislava: Veda.

GAHÉR, F. (2019): Je Mill naozaj predchodca známeho vysvetlenia kontrafaktuálov? Filozofia 74 (4), 259 - 277. DOI: https://doi.org/10.31577/filozofia.2019.74.4.1

HAMBLIN, C .L. (1970): Fallacies. London: Methuen and Co.

HANSEN, H. (2019): Fallacies, The Stanford Encyclopedia of Philosophy (Fall 2019 Edition). Zalta, E. N. (ed.). Dostupné na: < https://plato.stanford.edu/archives/fall2019/entries/fallacies/ > (Navštívené: 20. 8. 2019).

JEVONS, S. W. (1877): John Stuart Mill's Philosophy Tested [I], Contemporary Review, 31 (Dec.), $167-182$.

JEVONS, S. W. (1878): John Stuart Mill's Philosophy Tested II, Contemporary Review, 31 (Jan.), 256 - 275.

JONGSMA, C. (1982): Richard Whately and the Revival of Syllogistic Logic in Great Britain in the Early Nineteenth Century. Toronto: University of Toronto (PhD dissertation).

KETT, H. (1802): Elements of General Knowledge, introductory to useful books in the principal branches of Literature and Science. With List of the most approved Authors; including the best editions of the Classics. Designed chiefly for the junior students in the Universities, and the higher classes in Schools, 2 vols. Oxford: Oxford University Press.

KETT, H. (1809): Logic made Easy; or, a Short View of the Aristotelic System of Reasoning, and its Application to Literature, Science, and the General Improvement of the Mind. Designed chiefly for the Students of the University of Oxford. Oxford: Oxford University Press.

KIRWAN, R. (1807): Logick, or an Essay on the Elements, Principles, and Different Modes of Reasoning. 2 Vols. London: Payne \& Mackinley.

KNEALE, W., KNEALE, M. (1962/1984): The Development of Logic. Reprint Oxford: Clarendon Press.

KNIGHT, P., PLAYFAIR, J., SMITH, S. (1810): Columnies Against Oxford. (Review of E. Copleston 1810 Reply). Edinburgh Review.16 (31), 158 - 187.

LOIZIDES, A. (ed.) (2014): Mill's System of Logic: Critical Appraisals, London: Routledge.

MILL, J. S. (1828): Whately's Elements of Logic. Westminster Review IX, 137 - 172.; Reprint In: Robson, J. M. (ed.): Mill, J. S.: The Collected Works of John Stuart Mill, Volume XI-Essays on Philosophy and the Classics. Introduction by Sparshott, F. E. Toronto: University of Toronto Press, London: Routledge and Kegan Paul, 1978.

MILL, J. S. (1843/1974): A System of Logic, Ratiocinative and Inductive: Being a Connected View of the Principles of Evidence and the Methods of Scientific Investigation. Reprint. In: Robson, J. M. (ed.): The Collected Works of John Stuart Mill, Volume VII. Introduction by McRae, R. F. Toronto: University of Toronto Press, London: Routledge and Kegan Paul.

MILL, J. S. (1873/1981): John Stuart Mill, Autobiography (Parallel Reading Texts of the Early Draft and the Columbia MS). Reprint In: Robson, J. M. - Stillinger, J. (eds.): The Collected Works of John Stuart Mill, Vol. I - Autobiography and Literary Essays. Introduction by Robbins, L. Toronto: University of Toronto Press, London: Routledge and Kegan Paul. Dostupné na: $<$ https://oll.libertyfund.org/titles/242>. (Navštívené: 14. 10. 2019).

PLAYFAIR, J. (1808): Traité de méchanique céleste. Edinburgh Review, January, 11 (22), 249 - 84.

PLAYFAIR, J. (1810): Woodhaus's Trigonometry. Edinburgh Review, November, 17 (33), 125 - 35.

SCARRE, G. (1984): Proof and Implication in Mill's Philosophy of Logic. History and Philosophy of Logic, 5 (1), 19 - 37.

SCARRE, G. (1989): Logic and Reality in the Philosophy of John Stuart Mill. Dordrecht: Kluwer. 
SKORUPSKI, J. (1989): John Stuart Mill. London: Routledge.

STACK, D. (2018): The hostility of William Stanley Jevons towards John Stuart Mill: the fourth dimension. History of Political Economy. Durham: Duke Univesity Press. Dostupné na: $<$ http://centaur.reading.ac.uk/ 79392/1/HPEJevonsStack.pdf> (Navštívené: 10. 8. 2019).

WALKER, J. (1805/1847): Murray's Compendium of Logic: With a Corrected Latin Text. Dublin: Cumming and Ferguson.

WHATELY, R. (1826/1855): Elements of Logic. Comprising the Substance of the Article in the Encyclopaedia Metropolitana, with Additions. London: Mawman, Boston - Cambridge: Munroe.

Whately, R. (1854): Remains of the Late Edward Copleston, Bishop of Llandaff: With an Introduction Containing Some Reminiscences of His Life. London: John W. Parker and Son.

Táto práca bola podporená projektom Agentúry pre podporu výskumu a vývoja č. APVV-17-0057 a grantom VEGA č. 1/0036/17.

František Gahér

Katedra logiky a metodológie vied

Filozofická fakulta

Univerzity Komenského v Bratislave

Gondova 2

81499 Bratislava

Slovenská republika

e-mail: frantisek.gaher@uniba.sk

ORCID ID: https://orcid.org/0000-0001-6892-1429 